\title{
Juridical Review of Child Drugs User in Indonesia
}

\author{
Imawan Sugiharto \\ Universitas Pancasakti Tegal, Indonesia \\ Email: imawansugiharto57@gmail.com
}

\begin{abstract}
Narcotics can endanger human life if misused and have very broad negative effects. This is indicated by the number of cases of drug users from year to year from various groups including children. Therefore, both the dealer and the user are charged with a very heavy article. This study aims to determine the dangers of narcotics abuse as well as a juridical review for underage offenders. The method used is the normative juridical method. From this research it is known that underage drug users are charged under Article 114 Paragraph (1) of the Law Number 35 of 2009 about Drugs.
\end{abstract}

Keywords: Narcotics, Abuse, Juridical, Children.

\section{A. INTRODUCTION}

Development in Indonesia includes physical development and human resources. This becomes increasingly difficult because of the many effects of drug abuse as an organized crime, which affects various fields and groups, including children (Soedjono, 2004). Narcotics crimes are organized crimes with a wide network and large funds (Bond, 1931). Referring to the KPAI on drug abuse cases, during the period 2011-2014 the increase in cases in children reached nearly $400 \%$. The National Narcotics Agency also stated that in 2014, as many as 33\% of narcotics users and dealers were students and students (Zahra, 2017).

In essence, the juvenile criminal justice system prioritizes protection and rehabilitation (Yingchun, 2009). Children are protected by society and the state as assets of the nation. The minimum possible effort in the intervention of the criminal justice system by children is something that needs to be done (Young, 1995). It is affirmed in Article 16 Paragraph (3) of Law Number 23 Year 2003 concerning Child Protection, that; "Arrest, detention, or child imprisonment is only carried out if it is in accordance with applicable law and can only be done as a last resort."

However, the facts on the ground are that many child offenders are convicted and imprisoned with different lengths of detention (Hidayat, 2018). The consideration is that the perpetrator has committed a violation of norms (interference with legal order) which someone has deliberately or unintentionally committed to and the punishment of the perpetrator is deemed necessary for the sake of maintaining legal order (Lamintang, 1997).

Based on the description above, the researcher feels the need to study and examine more deeply the juridical review for offenders of narcotics abuse by children. 


\section{B. METHOD}

The method used in this research is juridical normative with analytical descriptive specifications. In this study, the scope of research includes how to draw legal principles, where this is done to written positive law. With deductive thinking methods and using data collection tools, namely: literature study and documentary study.

\section{RESULTS AND DISCUSSION}

A criminal act is an act which is prohibited by a criminal law and is punishable by any person who violates the prohibition. The elements of a crime include subjective elements and objective elements (Dwiatmojo, 2013).

The subjective element is an element that is attached to the doer or related to the doer, including the intention. In no punishment, this element includes:

a. Deliberate or unintentional (dolus or culpa)

b. Purpose (voonemen) in an experiment or poging

c. Various purposes (oogemerk), for example, fraud.

d. Planned (voorbedachte raad). For example murder.

e. Fear (Vres)

The objective element is an element related to the condition of the perpetrator when he did not commit a crime. In a criminal act these elements include: Human actions: Act (active actions) and Ommission (passive actions).

a. As a result of action: Namely things that are harmful or damaging, even eliminating the interests that are defended by law.

b. Conditions: The state at the time of doing and the state after doing.

c. Unlawful: This is in the form of a unit of proven offense (Dwiatmojo, 2013).

Criminal acts can be differentiated based on certain criteria (Sudanto, 2017), for example:

a. Based on how to formulate it

1) Formal Crime (formeel delicten)

2) Materil Crime (material delicten)

b. Based on the form of the error

1) Delict Dolus (contains elements of deliberation)

2) Delict Cupaldi (contains an element of negligence)

c. Based on the type of action

1) Delict Commisions (committed crimes, such as mistreatment)

2) Delict Amissionis (not before the court as a witness)

d. Based on the complaint offense

1) Absolute Complaint Crime

2) Relative Complaint Crime

3) Non-Complaint Crime

Narcotics commonly known in the community are narcotics used in the medical world, but are often misused for certain purposes. Namely people who use narcotics without rights or against the law (Manning, 1997). In general, narcotics 
crime can be divided into several categories as follows:

a. Narcotics abuse crime: Acting against others and oneself

b. Criminal acts concerning the production and sale and purchase of narcotics. Covering exports and imports.

c. Criminal acts regarding the transportation of narcotics. includes carrying, sending, transporting, and transiting narcotics.

d. Criminal acts regarding possession of narcotics.

e. Criminal acts of not reporting narcotics addicts.

f. Criminal acts concerning labels and publications.

g. Criminal acts regarding the confiscation and destruction of narcotics. The status of evidence is determined in a court decision if the evidence is proven to be used for a crime.

h. Criminal acts involving the use of minors.

The Narcotics Law has regulated the forms of narcotics abuse, for example in Article 114 Paragraph (1) the Narcotics Law states that: "Every person who without rights or against the law offers to sell, sell, buy, accept, become an intermediary in buying and selling, exchanging, or handing over narcotics Category I, shall be punished with life imprisonment or imprisonment for a minimum of 5 (five) years and a maximum of 20 (twenty) years and a fine of at least Rp. 1,000,000,000.00 (one billion Rupiah) and a maximum of Rp. 10,000,000,000.00 (ten billion Rupiah)".

In accordance with Article 114 Verse (1) of the Narcotics Law above, it shows that the Law determines all actions without rights or against the law to offer for sale, sell, buy, receive, become an intermediary in the sale, exchange, or hand over narcotics Category I because very dangerous and has an effect on increasing crime. If this is done, it can be categorized as an act of narcotics abuse (a special crime) which can be threatened with legal sanctions as mentioned above.

The Law of the Republic of Indonesia Number 35 of 2009 has regulated the criminal act of narcotics in Chapter XV Articles 111 to 148 which are special provisions (Ariyanti, 2017). In the Narcotics Law, actions that are declared as criminal acts are as follows:

a. Without the right, or against the law to plant, maintain, possess, keep, control, or provide narcotics group I in the form of plants (Article 111).

b. Without rights, or against the law owning, controlling, or providing narcotics Category I non-plants (Article 112).

c. Without the right, or against the law to produce, import, export, or distribute narcotics Category 1 (Article 113).

d. Without the right, or against the law to offer to sell, sell, buy, receive, become an intermediary in the sale and purchase, exchange, or hand over narcotics Category 1 (Article 114).

e. Without rights, or against the law carrying, sending, transporting, or transiting Narcotics Category I (Article 115).

f. Without rights, or against the law to use narcotics Golonga I against other people or to give narcotics Category I for the use of others (Article 116). 
g. Without the right, or against the law to own, keep, control or provide narcotics Category II (Article 117).

h. Without the right, or against the law to produce, import, export, or distribute narcotics Category II (Article 118).

i. Without the right, or against the law to offer to sell, sell, buy, receive, act as an intermediary in the sale and purchase, exchange, or hand over narcotics Category II (Article 119).

j. Without the right, or against the law to carry, send, transport, or transfer narcotics Category II (Article 120).

k. Without the right, or against the law, using Category II narcotics against other people or providing Category II narcotics for the use of others (Article 121).

1. Without the right, or against the law to own, keep, own or provide narcotics Category III (Article 122).

$\mathrm{m}$. Without the right, or against the law to produce, import, export, or distribute narcotics Category III (Article 123).

n. Without the right, or against the law to offer to sell, sell, buy, receive, act as an intermediary in the sale and purchase, exchange, or hand over narcotics Category III (Article 124).

o. Without the right, or against the law to carry, send, transport, or transfer narcotics Category III (Article 125).

p. Without the right, or against the law to use narcotics group III against other people or to give narcotics Category III for the use of other people (Article 126). (Ridha, 1987)

The definition of a child varies from one another, because there is no specific limit on who is defined or categorized as a child (Giroud, 2000). However, the Civil Code has various statutory provisions regarding children. In these various provisions, there are no specific regulations regarding the criteria for children. Such as the following:

a. According to the Civil Code, Article 330 stipulates that a minor is they have not reached the even age of 21 (twenty one) years and have not yet married.

b. According to the Criminal Code, in Article 45, a child is not yet an adult if he is not yet 16 (sixteen) years old. If the victim of crime (Chapter XIV) is less than 15 (fifteen) years old.

c. According to Law Number 12 of 1995 Challenging Corrections, in Article 1 Paragraph (8) it is determined that correctional students, both criminal children, state children, and civilian children who are educated in prisons are 18 (eighteen) years old at the latest.

d. According to Law Number 32 of 2014 concerning amendments to Law Number 23 of 2002 concerning Child Protection, in Article 1 Paragraph (1) a child is a person who is not yet 18 (eighteen) years old including children who are in the womb. 
e. According to Law Number 11 of 2012 concerning the Criminal Justice System for Children, Article 1 Paragraph (3) explains that a child is a child who is 12 (twelve) years old, but not yet 18 (eighteen) years old who is suspected of committing an act. criminal.

Children receive special protection as stated in Article 59 of the Child Protection Law as follows: "The government, local governments, and other state institutions are obliged and responsible for providing special protection to children". Furthermore, Article 59 Verse (2) reads: "Special protection for children" as referred to in paragraph (1) is given to:

a. Child in emergency situations;

b. Children in conflict with the law;

c. Children from minority and isolated groups;

d. Children who are exploited economically and / or sexually;

e. Children who are victims of narcotics abuse

f. Children with HIV/AIDS;

g. Child victims of kidnapping, sale, and / or trafficking;

h. Child victims of physical and / or psychological violence;

i. Child victims of sexual crimes;

UUSPPA categorizes two types of sanctions, namely action, for criminal offenders who are under 14 years old (Article 69 Paragraph (2) of the SPPA Law) and criminal, for criminal offenders aged 15 years and over.

a. Action sanctions that can be imposed on children include (Article 82 of the SPPA Law)

1) Return to parent / guardian; Submission to someone;

2) Treatment in a mental hospital.

3) Treatment at LPSK.

4) The obligation to attend formal education and/or training held by the government or private bodies;

5) Revocation of Drive Licence;

b. Criminal Sanctions

Criminal sanctions that can be imposed on child offenders are divided into Basic Crime and Additional Criminal (Article 71 UU SPPA): Basic Crime and Additional Criminal. The principal crimes are divided into: Criminal warning; Criminal with conditions, which consist of: guidance outside institutions, community services, or supervisors; Job training; Development within the institution; and Prison. Additional Criminal consists of: Deprivation of profit from a criminal act, and Fulfillment of customary obligations.

In deciding sanctions for juvenile offenders, judges have considerations about things that lighten or aggravate cases in court (Liberman, 2011). This is in accordance with the formulation of Article 183 of the Criminal Procedure Code which states that a judge may not impose a sentence on a person unless with at least two valid evidences he is convinced that a crime actually occurred and that the defendant was guilty of committing it (Mardani, 2008). 
a. Lightening Things

The reduction of sentences based on the provisions of the Law according to Leden Marpaung (2005), is as follows:

1) In the case of a young age (incapacity or infacy), based on Article 47 paragraph (1) of the Criminal Code, which reads as follows: "If the judge punishes the child who is guilty, the maximum basic sentence for the crime will be reduced by one third."

2) In the case of trying to commit a crime, based on Article 53 paragraph (2) of the Criminal Code which reads as follows: "The maximum principal sentence determined for the crime is reduced by one third in the case of probation."

3) In terms of assisting in committing crimes, based on Article 57 paragraph (1) which reads as follows: "The maximum basic sentence determined for the crime is reduced by one third for the maid."

b. Burdensome Things

1) Additional penalties based on law are determined as follows: In the case of Concursus, as stipulated in Article 65 of the Criminal Code:

a) In the case of a combination of several acts which must be viewed as separate acts so that they constitute several crimes, which are punishable by the same basic punishment, only one punishment shall be imposed.

b) The maximum sentence imposed is the maximum number of penalties that are punishable against said act, however, it cannot be more than the maximum maximum penalty plus one third.

2) Article 66 of the Criminal Code which states:

a) In the case of a combination of several acts, each of which must be viewed as an independent act so that it constitutes several crimes, which are punishable by different principal crimes, then the penalty for each crime is imposed, but the number may not be more than the maximum of the heaviest plus. one third.

b) In this case, the fine is calculated according to the maximum length of substitute imprisonment determined for the offense.

\section{CONCLUSION}

The application of Material Criminal Law to the Crime of Narcotics Abuse by Children is basically correct by using 2 (two) charges, namely: Primair Article 114 Verse (1) of Law of the Republic of Indonesia Number 35 of 2009 concerning Narcotics, and Subsidies Article 112 Verse (1) Law of the Republic of Indonesia Number 35 of 2009 concerning Narcotics. However, there are many cases where the punishment is inappropriately handed down by the judge to the child offender who does not meet the criteria for imprisonment. 


\section{REFERENCES}

1. Ariyanti, V. (2017). Kedudukan Korban Penyalahgunaan Narkotika dalam Hukum Pidana Indonesia dan Hukum Pidana Islam. Al-Manahij: Jurnal Kajian Hukum Islam, 11(2), 247-262.

2. Bond, J. D. (1931). Entrapment in Narcotic Law Violations. Kentucky Law Journal, 20(1), 10.

3. Dwiatmodjo, H. (2013). Pelaksanaan pidana dan pembinaan narapidana tindak pidana narkotika (Studi terhadap Pembinaan Narapidana di Lembaga Pemasyarakatan Narkotika Klas IIA Yogyakarta). Perspektif, 18(2), 64-73.

4. Giroud, C., Felber, F., Augsburger, M., Horisberger, B., Rivier, L., \& Mangin, P. (2000). Salvia divinorum: an hallucinogenic mint which might become a new recreational drug in Switzerland. Forensic Science International, 112(2-3), 143-150.

5. Hidayat, M. (2018). Juridical Review of Decriminalization on Efforts to Cut Drugs Users' Addiction In Indonesia. YURISDIKSI: Jurnal Wacana Hukum dan Sains, 11(2), 1-12.

6. Lamintang, P. A. F. (1997). Dasar-Dasar Hukum Pidana Indonesia. Bandung: Citra Aditya Bhakti.

7. Liberman, J. (2011). Implications of international law for the treatment of cancer: the Single Convention on Narcotic Drugs and the TRIPS Agreement. Public Health, 125(12), 840-846.

8. Makaro,. M.T. (2005). Tindak Pidana Narkotika. Bogor: Ghalia Indonesia

9. Manning, P. K., \& Redlinger, L. J. (1977). Invitational edges of corruption: Some consequences of narcotic law enforcement. Drugs and Politics, 279-310.

10. Mardani. (2008). Penyalahgunaan Narkotika dalam perspektif Hukum Islam dan Hukum Pidana Nasional. Jakarta: Raja Grafindo Persada.

11. Ridha, M. (1987). Narkotika, Masalah dan Bahayanya. Jakarta: Bina Aksara.

12. Sudanto, A. (2017). Penerapan Hukum Pidana Narkotika di Indonesia. ADIL: Jurnal Hukum, 8(1), 137-161.

13. Soedjono, A. (2004). Patologi Sosial. Bandung: Alumni

14. Willig, S. H. (1968). Some Applications of Drug, Device and Narcotic Laws for Health Science Practitioners. Food, Drug, Cosmetic Law Journal, 23(2), 89-104.

15. Young, J. H. (1995). Federal Drug and Narcotic Legislation. Pharmacy in History, 37(2), 59-67.

16. Yingchun, W. (2009). An Analysis of the New Rehabilitation System in the Law on Narcotic Control. Journal of Railway Police College, (5), 9.

17. Zahra, A., \& Sularto, R. B. (2017). Penerapan Asas Ultimum Remedium Dalam Rangka Perlindungan Anak Pecandu Narkotika. Law Reform, 13(1), 18-27.

18. Zimmering, R.T \& Wortis, S. B. (1951). Heroin addiction in adolescent boys. The Journal of Nervous and Mental Disease, 114(1), 19-34. 